\title{
Testing of a torque sensor used to measure the parameters of the briquetting process of lignocellulosic materials
}

\author{
Krzysztof Talaśka ${ }^{1, *}$, Dominik Wojtkowiak ${ }^{1}$, Ireneusz Malujda ${ }^{1}$ and Krzysztof Wałęsa ${ }^{1}$ \\ ${ }^{1}$ Chair of Basics of Machine Design, Poznan University of Technology, Poznan, 60-965, Poland
}

\begin{abstract}
The study presents a control and measurement system for the drive parameters of screw compactor machine with open working chamber for shredded materials. The study demonstrates the construction and working principle of the torque sensor for measuring the torque of the motor driving the compacting screw. The calibration method for the measuring system was presented together with example measurement results for compaction of broken up rye straw, oat straw and hay. The study results were analyzed for feasibility of use for the compaction of materials with specific thermomechanical properties. The conclusion presents the possible forms of application of the established solution in mass production.
\end{abstract}

Keywords: worm/screw-based compaction machine, torque sensor

\section{Introduction}

Renewable solid fuels manufactured as a result of compaction of broken down lignocellulosic materials are a perfect alternative to fossil fuels. The main source of renewable solid fuels in Poland is straw from different species of grains. Particularly because Poland has a major overproduction from the cultivation of grain, the majority of straw production can be utilized for power generation. Table 1 presents the balance of the total production compared to the utilization in Poland in years 2010-2014. Additionally, it presents a forecast for the years 2010-2030 [1-8].

The compaction processes of powder and shredded materials influences the change of their mechanical and functional properties, as well as the conditions of transport and storage [9-15]. The manufacturing of solid fuels calls for the utilization of proper machines utilizing specific compaction techniques. The processing of different types of cut straw and hay, recognizes machines utilizing piston, screw and roller-based compression technique. Every approach calls for proper preparation of the material, both in regards its fragmentation and moisture. The piston and screw techniques are employed for compacting cut material comprising longer fragments, whereas roller based compaction calls for finely cut material. The ranges of thermomechanical property values of broken down lignocellulosic materials are broad. Even within the same species of plant, parameters such

${ }^{*}$ Corresponding author: krzysztof.talaska@put.poznan.pl

Reviewers: Grzegorz Domek, Andrzej Kołodziej 
as the place and conditions of vegetation can affect their properties. Moreover, the broad range of moisture values serves to complicate the process even further.

Table 1. The balance of the total production and utilization of straw in the years 2010-2030 [1-8]

\begin{tabular}{|c|c|c|c|c|c|c|c|}
\hline & \multicolumn{7}{|c|}{ Year } \\
\hline & \multirow{2}{*}{2010} & \multirow{2}{*}{2011} & \multirow{2}{*}{2012} & \multirow{2}{*}{2013} & \multirow{2}{*}{2014} & \multicolumn{2}{|c|}{ Forecast } \\
\hline & & & & & & 2020 & 2030 \\
\hline $\begin{array}{l}\text { Production } \\
\text { tons] }\end{array}$ & 29.753 & 28.89 & 30.793 & 29.343 & 35.608 & 30.533 & 30.862 \\
\hline \multicolumn{8}{|l|}{\begin{tabular}{ll|}
$\begin{array}{l}\text { Utilization } \\
\text { tons }]\end{array}$ & [million \\
\end{tabular}} \\
\hline Mulch & 11.843 & 11.24 & 10.698 & 10.303 & 10.47 & 9.868 & 9.319 \\
\hline Fodder & 3.923 & 3.914 & 3.898 & 3.763 & 3.806 & 3.527 & 3.221 \\
\hline Green manure & 3 & 3 & 3 & 3 & 3 & 3 & 3 \\
\hline Bedding for mycelit & 1 & 1 & 1 & 1 & 1 & 1 & 1 \\
\hline Balance & 9.987 & 9.736 & 12.198 & 11.277 & 17.322 & 13.138 & 14.322 \\
\hline
\end{tabular}

One of the most widespread methods of cut straw compaction is its agglomeration utilizing screw compaction machines. Fig. 1 presents a diagram of such a machine. The main working unit comprises an worm screw (cylindrical or conical) performing a rotating motion in a forming sleeve (cylindrical or conical). The utilization of such a working system allows to form agglomerate with diameter of several dozen millimeters with an orifice. Such final geometric form of the agglomerate material facilitates the evaporation of moisture as a result of it being heated up in the course of the agglomeration process.



Fig. 1. Worm/screw-based compaction machine with open forming sleeve used in the manufacturing of briquette from broken down lignocellulosic materials: 1 - drive motor, 2 - mechanical transmission, 3 - compacted material, 4 - worm, 5 - heated forming (compacting) sleeve, 6 - final geometric form of the agglomerate 


\section{Process parameters for the compaction of lignocellulosic materials utilizing compacting screw technique}

The final geometric form of the agglomerate depends on the geometric features of the worm and the forming sleeve. Fig. 2 presents the breakdown of the main geometric parameters of the working system of the compacting machine. The worm drive can be defined by two parameters: torque $T_{r}$ and axial force $F_{a}$. Their measurement can be of critical importance for the purpose of control and the construction of the control system of the compaction process. The working conditions for the compaction machines are demanding: elevated temperature, high dustiness, variable loads. There are no known construction solutions to be used for measuring e.g. the torque $T_{r}$. To this end, an attempt was made to test the construction solution protected by Polish patent no. 225808.

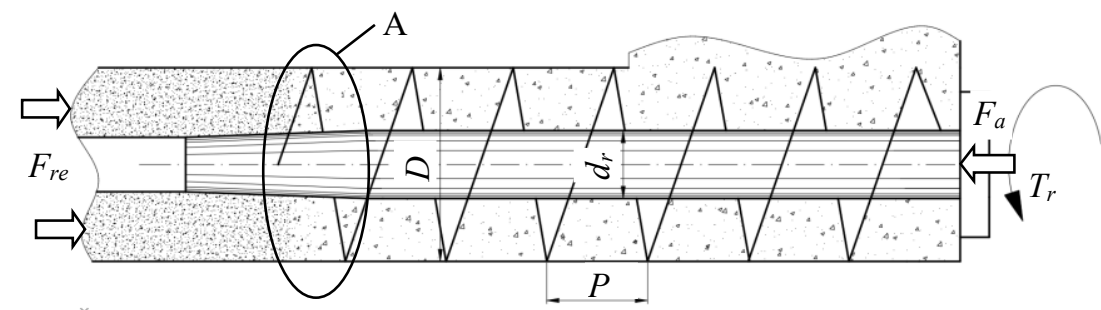

Fig. 2. Geometric properties of the working system of the compaction machine for broken down lignocellulosic materials (compacting screw technique): $D$ - diameter of the cylindrical part of the worm, $d_{r}$ - worm hub diameter, $P$ - worm pitch, $F_{r e}$ - resistance force, $F_{a}-$ axial force, $T_{r}-$ torque, A - main compaction area of the material

Fig. 3 demonstrates the construction diagram of the tested solution.


Fig. 3. Torque meter: 1 - turning shaft, 2 - body, 3 - body, 4 - idler, 5 - chain wheel, 6,7 - idler shaft bearings, 8 - chain wheel bearings, 9 - screws, 10 - protecting pin, 11 - induction sensors, 12 - slot with inlet groove for the installation of worm pin, 13 - groove limiting the range of motion, $\gamma$ - twisting angle of the turning shaft $[8,16]$

The operating principle is based on indirect determination of the torque vale based on the twisting angle of the turning shaft 1 . It was made of spring steel which allows to obtain 
relatively large vales of the twisting angle. The twisting angle is measured based on the difference in the occurrence of impulses at induction sensors. The disadvantage of such a solution is the possibility to perform measurement only at constant rotation speed. Additionally, in order to obtain actual results, it is necessary to average the calculated value from the time range e.g. 1-3 s. Calibration of the torque meter assembly entails determining the value of the twisting torque as a function of the twisting angle. With such information it is possible to determine the torque value.

\section{Methodology and scope of test measurements}

The examination was carried out on a compaction machine utilizing compaction worm screw. The compaction process was undertaken for oat straw, rye straw and hay (Fig. 4). The examination was carried out for three rotation speeds of the worm: 210, 280 and 350 rpm. Figs. 5-7 present the example results of the examination. Table 2 presents a breakdown of the collected examination results for the three materials and three rotation speeds of the worm.

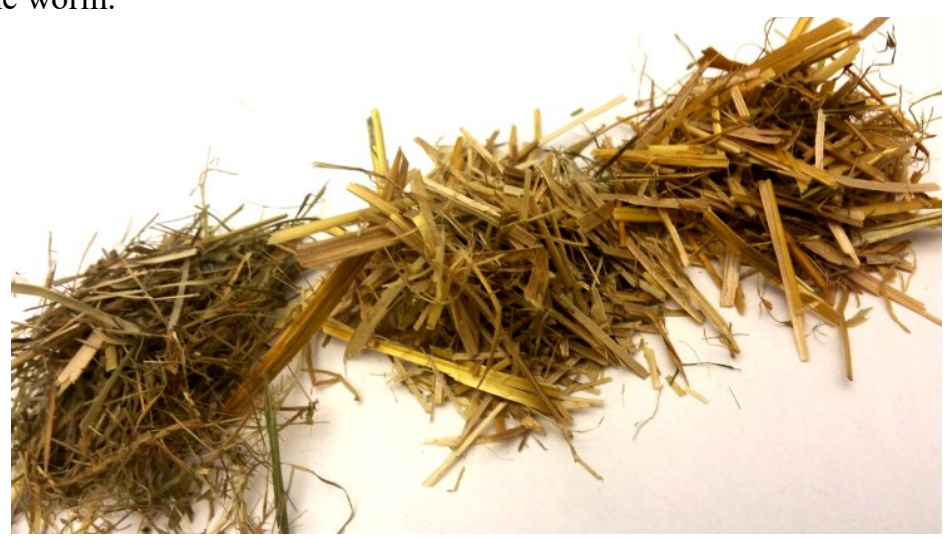

Fig. 4. Materials used for the examination: oat straw, rye straw, hay



Fig. 5. The change of torque $M_{o}$ as a function of time; rye straw 




Fig. 6. The change of torque $M_{o}$ as a function of time; oat straw

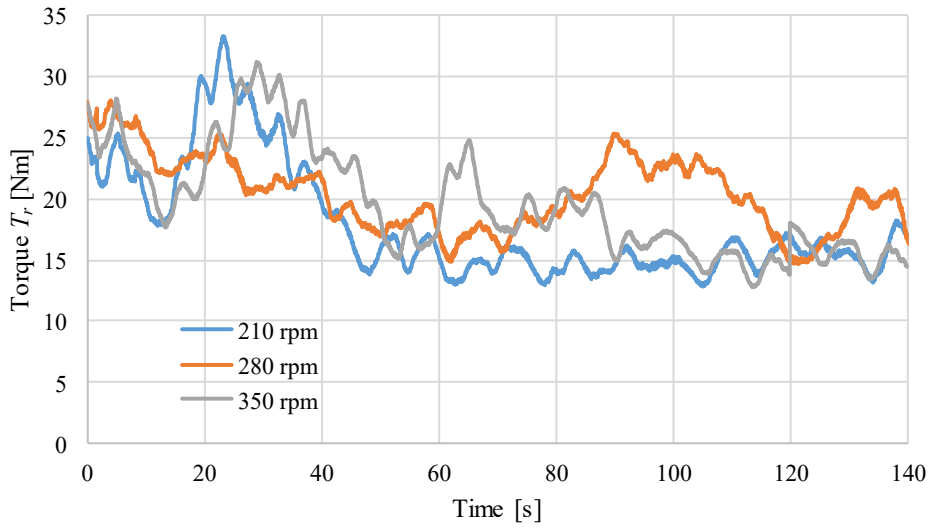

Fig. 7. The change of torque $M_{o}$ as a function of time; hay

Table 2. Breakdown of results of the examination of the torque $M_{o}$

\begin{tabular}{|l|c|c|c|}
\hline \multirow{2}{*}{ Material } & \multicolumn{3}{|c|}{ Torque $M_{o}[\mathrm{Nm}]$} \\
\cline { 2 - 4 } & $n_{s 1}$ & $n_{s 2}$ & $n_{s 3}$ \\
\hline Rye straw & $19.6-40.5$ & $25.3-39.4$ & $24.1-40.2$ \\
\hline Oat straw & $17.2-25.6$ & $22.2-31.5$ & $26.4-39.2$ \\
\hline Hay & $13.7-33.8$ & $15.1-27.8$ & $13.6-31.3$ \\
\hline
\end{tabular}

\section{Summary}

The examined torque meter utilizes the phenomenon of twisting of the rotating shaft in order to determine the torque value, it is utilized with compacting machines utilizing worm screw technology. Similarly to the axial force load on the worm, the torque value also changes in a wide range during the compaction process of the selected material. This is caused by the heterogeneous thermomechanical properties of broken down lignocellulosic materials. Controlling the base parameters of the compaction process is highly beneficial from the standpoint of exercising control over the machine. Examination results indicate that different materials may call for similar working parameters. This prevents designing dedicated working systems for specific materials. It is therefore much more advantageous 
to utilize dedicated measurement systems allowing to monitor selected parameters during machine operation. This allows to monitor the process and control it as required.

\section{References}

1. GUS: Characteristics of farms in 2013 (in Polish), Warszawa (2014)

2. GUS: Production of agricultural and horticultural crops in 2014 (in Polish), Warszawa (2015)

3. GUS: Land and sown area use in 2014 (in Polish), Warszawa (2015)

4. GUS: Livestock in 2014 (in Polish), Warszawa (2015)

5. A. Faber, J. Kuś, Alternative directions of production of Polish agriculture (in Polish), Pamiętnik Puławski, 132, pp. 59-73 (2003)

6. Cz. Maćkowiak, Straw as a fertilizer on a farm without inventory (in Polish), Wieś Jutra, 5, pp. 46-48 (1998)

7. A. Madej, Straw balance in Poland in 2010-2014 and forecast by 2030 (in Polish), Stowarzyszenie Ekonomistów Rolnictwa i Agrobiznesu, Roczniki Naukowe, t. XVIII, z. 1, pp. 163-168 (2016)

8. K. Talaśka, Study of research and modelling of compaction processes of powder and shredded materials (in Polish), Wydawnictwo Politechniki Poznańskiej, Poznań (2018)

9. K. Talaśka, I. Malujda, D. Wilczyński, Agglomeration of natural fibrous materials in perpetual screw technique - a challenge for designer, Procedia Engineering, 136, pp. 63-69 (2016).

10. D. Wilczyński, K. Talaśka, I. Malujda, R. Długi, The Study of Mechanical Properties of Natural Polymers in the Compacting Process, Procedia Engineering, 177, pp. 411418 (2017)

11. I. Malujda, D. Wilczyński, Mechanical Properties Investigation of Natural Polymers, Procedia Engineering, 136, pp. 263-268 (2016)

12. D. Wilczyński, K. Talaśka, I. Malujda, P. Jankowiak, Experimental research on biomass cutting process, MATEC Web of Conferences, 157, Article Number 07016 (2018)

13. J. Górecki, I. Malujda, K. Talaśka, M. Kukla, P. Tarkowski, Influence of the compression length on the ultimate stress in the process of mechanical agglomeration of dry ice, Procedia Engineering, 177, pp. 363-368 (2017)

14. J. Górecki, I. Malujda, K. Talaśka, P. Tarkowski, M. Kukla, Influence of the value of limit densification stress on the quality of the pellets during the agglomeration process of $\mathrm{CO}_{2}$, Procedia Engineering, 136, pp. 269-274 (2016)

15. J. Górecki, I. Malujda, K. Talaśka, D. Wojtkowiak, Dry ice compaction in piston extrusion process, Acta mechanica et automatica, 11, pp. 313-316 (2017)

16. Płotkowiak J., Adamiec J., Dudziak M., Malujda I., Talaśka K.: Momentomierz, Patent nr 225808, Warszawa (2017) 